\title{
Original Research \\ Qualification, knowledge and experience of dispensers working at community pharmacies in Pakistan
}

\author{
Azhar HUSSAIN, Mohamed Izham M. IBRAHIM. \\ Received (first version): 18-Oct-2010 Accepted: 19-May-2011
}

\begin{abstract}
${ }^{*}$
Pharmacies are managed by a variety of dispensers in terms of qualification, knowledge and experience in Pakistan.

Objective: The study aimed to document the state of knowledge, experience and qualification of dispensers working at community pharmacies in Pakistan.

Methods: A comparative cross sectional study was conducted at a randomly selected sample of 371 pharmacies in the three cities of Pakistan. A structured questionnaire for data collection was developed and finalized by focused group discussions and pilot testing. The data was coded, entered and analyzed by using SPSS Version 16. Kruskal-Wallis and Mann-Whitney tests ( $p \leq 0.05)$ were performed to find out differences.

Results: Out of total sample of 371 pharmacies, $31.8 \%(118)$ were in Islamabad, $32.4 \%(120)$ in Peshawar and $35.8 \%$ (133) were in Lahore. Fifty percent of the respondents had correct knowledge of range of room temperature at which medicines should be stored. Only $11.1 \%(41)$ of the respondents knew about OTC (over the counter drugs) which can be sold without prescription while $5.9 \%(22)$ of the respondents were aware of POM (prescription only medicines) which can be only sold on a valid prescription. While $87.6 \%$ (325), $88.1 \%$ (327), $58.7 \%$ (318) and $95.7 \%$ (355) of the respondents did not know the meaning of the dispensing abbreviations such as 'h.s', 'q.d', 'sos' and 'p.r.n'. The respondents did not know correctly the status of Deltacortil $\circledast$ (Prednisolone), Septran $®$ (Sulfamethoxazole) and Fansidar ${ }^{\circledR}$ (Pyrimethamine and Sulfadoxine) either as OTC or POM in $26.7 \%$ (99), $64.2 \%$ (238), and $44.5 \%$ (165) of the cases, respectively. There was a significant difference $(p \leq 0.05)$ in knowledge of dispensers regarding storage temperature, prescription terminologies and status of medicines having different level of qualification and experience.

Conclusions: The overall knowledge and training of dispensers working at community pharmacies is inadequate in Pakistan. However, pharmacists had relatively better knowledge regarding storage
\end{abstract}

\footnotetext{
Azhar HUSSAIN. PhDScholar School of Pharmaceutical Sciences, Discipline of Social and Administrative Pharmacy, University Sains Malaysia Penang (Malaysia) and Associate Professor. Hamdard Institute of

Pharmaceutical Sciences Hamdard University, Islamabad (Pakistan).

Mohamed Izham M. IBRAHIM. BPharm (Hons), PhD

Professor of Social \& Administrative Pharmacy College of Pharmacy, Al Qassim University. Al Qassim, (Saudi Arabia).
}

temperature, prescription terminologies and status of medicines as compared to pharmacy assistants, diploma holders and salesperson.

Keywords: Pharmacists' Aides. Professional Competence. Pharmacies. Pakistan.

\section{CUALIFICACIÓN, CONOCIMIENTO Y EXPERIENCIA DE LOS DISPENSADORES QUE TRABAJAN EN FARMACIAS COMUNITARIAS EN PAKISTÁN}

\section{RESUMEN}

En Pakistán, las farmacias están gestionadas por una variedad de dispensadores en cuanto a cualificación, conocimiento y experiencia. Objetivo: El estudio trató de documentar el estado del conocimiento, experiencia y cualificación de los dispensadores que trabajan en farmacias comunitarias en Pakistán.

Métodos: Se realizó un estudio comparativo transversal en una muestra aleatoria de 371 farmacias en tres ciudades de Pakistán. Para recoger los datos, se desarrolló un cuestionario semi-estructurado y se finalizó con un grupo focal y una prueba piloto. Los datos se codificaron y analizaron utilizando un SPSS versión 16. Se realizaron tests de Kruskal-Wallis and MannWhitney tests $(\mathrm{p} \leq 0.05)$ para identificar las diferencias.

Resultados: De la muestra total de 371 farmacias, el 31,8\% (118) estaban en Islamabad, el 32,4\% (120) en Peshawar y el 35,8\% (133) en Lahore. El $50 \%$ de los respondentes tenían un conocimiento correcto del rango de temperaturas a las que deben almacenarse los medicamentos. Sólo el 11,1\% (41) sabía que los OTC (over-the-counter) pueden venderse sin receta, mientras que el 5,9\% (22) era consciente que las POM (medicamentos con receta) que sólo pueden ser vendidos con una receta válida. El $97,6 \%$ (325), 88,1\% (327), 58,7\% (318) y $95,7 \%$ (355) de los respondentes no sabía el significado de las abreviaturas de dispensación tales como 'h.s', 'q.d', 'sos' y 'p.r.n'. Los respondentes no sabían correctamente el estado de Deltacortil ${ }^{\circledR}$ (Prednisolona), Septran ${ }^{\circledR}$ (Sulfametoxazol) y Fansidar ${ }^{\circledR}$ (Pirimetamina y Sulfadoxina) como OTC o POM en el 26,7\% (99), 64,2\% (238), y $44,5 \%$ (165) de los casos, respectivamente. Hubo una diferencia significativa $(\mathrm{p} \leq 0.05)$ en el conocimiento de los dispensadores sobre la temperatura de almacenamiento, terminología de prescripción y estado de los medicamentos cuando 
tenían diferente nivel de cualificación y experiencia.

Conclusiones: El conocimiento y formación generales de los dispensadores que trabajan en farmacias comunitarias en Pakistán es inadecuado. Sin embargo, los farmacéuticos tienen mejor conocimiento en relación a temperatura de almacenamiento, terminologías de prescripción y estado de los medicamentos comparados con los Auxiliares de farmacia, los diplomados y los vendedores.

Palabras clave: Auxiliares de farmacéuticos. Competencia Profesional. Farmacias. Pakistán.

\section{INTRODUCTION}

Community pharmacies in developing countries often lack qualified and trained personnel to store, label and handle medicines in appropriate way; mainly due to an acute shortage of qualified pharmacists practicing at community pharmacy setting and lack of standard practice guidelines. ${ }^{1}$ It has been reported that in most of the cases dispensers lack formal education and training and those who are trained are mostly not available at these pharmacies. ${ }^{2-5}$ While supplying medicines it is important to understand that which medicines can be sold with or without prescription. However studies have reported sale of prescription only medicines to all patients irrespective of any moral and legal considerations. ${ }^{3,6}$

The community pharmacies in Pakistan are known to be managed by a diversity of dispensers in terms of their qualification, knowledge and experience. ${ }^{7,10}$ Inadequate knowledge of the dispensers working at community pharmacies in Pakistan has been reported. $^{7,8}$ The qualification of dispensers vary from qualified pharmacist (degree of Bpharm/pharm D), pharmacy assistant (diploma in pharmacy), diploma holder (certified course of drug dispensing), to medical doctors, nurses and to the salesperson (people having no dispensing-related education) and majority constitutes of this group. ${ }^{1,7-9}$ These dispensers have minimal formal education with 10 to 12 years of schooling and with little or no professional training. ${ }^{1,7-9}$ Even this nominal education of primary or secondary level is seen as a commercial necessity and not as a legal requirement to be followed. They mostly rely on information gathered by the representatives of pharmaceutical companies thus selling medicines under the influence of promotion of medicines by the pharmaceutical companies. ${ }^{8}$ With this state of qualification and training, here these dispensers are responsible for the functions of a dispenser, store keeper, inventory manager, accountant, prescriber, information provider and patient counselor. ${ }^{10}$ Considering the scope of their services it seems that they are very specialized professionals having ample knowledge regarding dispensing practices. In real world, however, there is no real established criterion for minimum knowledge of dispensers and very little is known about their background experience, perceptions, education, training and knowledge on how they handle the technical tasks of storage of medicines, quality maintenance, and managing variety of patients with or without prescriptions. ${ }^{8,10-12}$

Accessibility and appropriate use of medicines are the foremost problems of the health care system in most of the developing countries. Health care systems cannot manage effectively with medicinerelated issues without the contribution of pharmacists. $^{1}$ Lack of dispensers qualification, knowledge and skills could lead to medication errors and increase adverse medicine outcomes, thus compromising at the desired therapeutic outcomes and safety of the therapy. ${ }^{21}$ Involvement of skilful and authoritative pharmacists in therapeutic procedures is necessary to improve appropriate use of medicines, eliminate medication errors and ensure maximum availability of medicines to the community. ${ }^{1}$ The inadequacies in qualification, scientific knowledge and skills of dispensers are contributing to the prevailing low quality services at community pharmacies.

Customers demand, social acceptance, commercial pressures and profit maximization have stronger impact on actual practice than regulations and clinical indications. Laws and regulations usually exists but the regulatory framework often lack resources for their effective execution and enforcement thus restraining their capacity to ensure the presence of qualified person at community pharmacies for good dispensing practices. $^{22}$

The importance of qualification, experience, training and knowledge of dispensers working at community pharmacies is not much emphasized in the country. The present study was conducted to document and compare the state of knowledge, experience and qualification of dispensers working at community pharmacies in three major areas of Pakistan.

\section{METHODS}

Keeping in view the federal administrative and regulatory structure of the country the capital city Islamabad was selected which is also geographically in the middle of the two provinces. Peshawar is located towards the north of Islamabad (184 Km away with 2 hours drive from federal capital) while Lahore is located in the south $(384 \mathrm{~km}$ away with 4.5 hours drive from federal capital). The study population included all community pharmacy outlets in Islamabad, Lahore and Peshawar cities, selling allopathic medicines. Pharmacies located in hospitals and private dispensaries were excluded and any outlet meeting this definition comprised the sampling unit, dispenser being the sampling element.

Simple random technique was used to draw the sample from the list of community pharmacies obtained from respective District Health Offices. The total population of pharmacies in Islamabad and Peshawar were 169 and 174 respectively. The list obtained from Lahore showed a figure of 3000 premises including pharmacies, distributors and whole-sellers, but when discussed with the drug 
inspectors of Lahore region it was found that the actual number of licensed pharmacies was not more than 1000-1200 in number. The reason being, the list was not updated from many years, it also included closed and or shifted premises and also whole-sellers and distributors as part. Keeping in view these issues the population of pharmacies in Lahore was considered as 1100 a total of 285 pharmacies were selected out of which only 133 pharmacies were visited due to logistical constraints. Sample size for pharmacies was calculated by using the formula by Glenn at $95 \%$ confidence interval [23] which was Islamabad $(n=118)$, Peshawar $(n=120)$ and Lahore $(n=133)$ and a total of $(n=371)$ community pharmacies in the three cities. The most experienced dispenser was selected from the pharmacy for interview.

Structured questionnaire was used to get information on the knowledge of the dispensers working at community pharmacies. The structured questionnaire was developed by focus group discussions and using the references of Drug Act of Pakistan 1976 and relevant rules under, Good Pharmacy Practices guidelines, International Pharmaceutical Federation (FIP) guidelines and inspection book of pharmacies. Two Focus group discussions were carried out at different time intervals with four different groups including community pharmacists, drug inspectors (Government officials who inspect quality of drugs and legal requirements at community pharmacies by drug law 1976 Pakistan), academia and members of consumer groups (NGO) each group comprising of three to four participants for the development, finalization, face and content validity of the structured questionnaire. Pilot testing was carried out at 37 pharmacies $(10 \%)$ of total sample size before execution of the final study. The value of cronbach's alpha was 0.726 which confirmed the reliability and internal consistency of the structured questionnaire.

The structured questionnaire comprised of a total of thirty three questions which included information on demographics, personal information, status in pharmacy, level of education, experience, training, sources of information, storage temperature, prescription terminologies, status of medicines, views and problems about profession and suggestions for improvement. The minimum requirement for knowledge of dispensers was elaborated and transformed into measurable indicators, which included three subscales: subscale I Knowledge about storage temperature (3-6), subscale II Knowledge about prescription terminologies (7-14) and subscale III Knowledge about status of medicines (12-24). The composite score for all sub scales was 22-44 and lower score referred to better compliance.

Data was collected by trained data collectors after seeking permission from relevant drug inspectors. Local chapters of chemist and druggist association were contacted and informed regarding the study. The study was also approved by the panel of experts at Research \& Development wing of Drug Control Organization at Ministry of Health,
Government of Pakistan. Informed and verbal consent for participation was taken from the respondents. Respondents were ensured for the confidentiality of information verbally as well as confidentiality under taking signed by the principal investigator was shown.

After the data collection, data was cleaned, coded and entered in SPSS version 16. Kruskal-Wallis and Mann-Whitney tests $(p \leq 0.05)$ were performed to compare the knowledge of dispensers regarding storage temperature, prescription terminologies and status of medicines among independent variables like urban/rural, cities, status of dispenser in pharmacy, experience, level of education and training.

\section{RESULTS}

A total of 371 dispensers were interviewed of which $31.8 \%$ (118) were working in Islamabad, $32.3 \%$ (120) in Peshawar and $35.8 \%$ (133) were in Lahore. All of the dispensers were male with mean age of 35 years, varying from 17 to 75 years. The status of dispensers in pharmacies was diverse $55 \%$ (207) owners, 35.3\% (148) employees, 2.7\% (10) spouse, and $1.6 \%$ (6) were licensee. The professional qualification of dispensers varied: $4 \%$ (15) were pharmacists, $7 \%$ (26) were pharmacy assistant, $6 \%$ (22) were dispenser diploma holders and $80.3 \%$ (298) had no pharmacy related education. Their experience was; $4 \%$ (15) less than a year, 9.7\% (36) between 1-2 years, $12.9 \%$ (48) between $2-5$ years and remaining $73.3 \%$ (272) had an experience greater than 5 years. Only 14\% (52) of the dispensers had formal training in drug dispensing.

Fifty percent of the respondents had correct knowledge of range of room temperature at which medicines should be stored. Refrigerators were available with $76.5 \%$ (288) of the pharmacies while $50.7 \%(188)$ of them were also selling vaccines. However $66 \%$ (248) did not knew which medicines to be kept in the refrigerator and knowledge of refrigerator and vaccine storage temperature. Only $11.11 \%$ (41) and $5.9 \%$ (22) of the respondents knew about the meaning of over the counter drugs and prescription only medicines respectively. However 87.6\% (325), 88.1\% (377), 58.7 (218) and $95.7 \%$ (355) did not know the meaning of abbreviations used in prescriptions such as h.s, q.d, sos and p.r.n. The respondents were not aware of the status of deltacortil, septran, fansidar, Augmentin, flagyl and lomotil as prescription only medicines in $26.7 \%$ (99), $64.2 \%$ (238), $44.5 \%$ (165), $50.4 \%$ (187), $77.4 \%(287)$ and $63.6 \%(236)$ of the cases respectively (Table 1 ).

Books were the most frequently used data source for information by dispensers. In $46.6 \%$ (173) cases dispensers were consulting Pharmaguide to get the desired information followed by British National Formulary $0.3 \%$ (1), Drug guide $0.3 \%$ (1) and British Pharmacoepia in $0.3 \%$ (1) of the cases (Table 2).

In addition to knowledge assessment of dispensers, study also included some questions to find general views/opinions of dispensers to get some insight 
Hussain A, Ibrahim MIM. Qualification, knowledge and experience of dispensers working at community pharmacies in Pakistan. Pharmacy Practice (Internet) 2011 Apr-Jun;9(2):93-100.

\begin{tabular}{|c|c|c|c|c|c|c|c|c|c|c|}
\hline \multirow{2}{*}{ Scale } & \multirow{2}{*}{ Indicator } & \multirow{2}{*}{ Description } & \multicolumn{2}{|c|}{ Islamabad } & \multicolumn{2}{|c|}{ Peshawar } & \multicolumn{2}{|c|}{ Lahore } & \multicolumn{2}{|c|}{ Composite } \\
\hline & & & $\mathrm{F}$ & $\%$ & $\mathrm{~F}$ & $\%$ & $\mathrm{~F}$ & $\%$ & $\mathrm{~F}$ & $\%$ \\
\hline \multirow{5}{*}{$\begin{array}{l}\text { Knowledge about } \\
\text { storage temperature }\end{array}$} & $\begin{array}{l}\text { Medications to be kept in } \\
\text { fridge }\end{array}$ & Yes & 36 & 28.8 & 31 & 25.8 & 59 & 44.4 & 123 & 33.2 \\
\hline & Sale of vaccine & Yes & 68 & 54.4 & 44 & 37 & 81 & 60.9 & 188 & 50.7 \\
\hline & $\begin{array}{l}\text { Temperature range for vaccine } \\
\text { storage }\end{array}$ & Yes & 66 & 52.8 & 13 & 10.8 & 46 & 34.6 & 123 & 33.2 \\
\hline & Room temperature range & Yes & 92 & 73.6 & 29 & 24.2 & 70 & 52.6 & 186 & 50.1 \\
\hline & Fridge temperature & Yes & 70 & 56.0 & 19 & 15.8 & 39 & 29.3 & 127 & 34.2 \\
\hline \multirow{9}{*}{$\begin{array}{l}\text { Knowledge about } \\
\text { prescription } \\
\text { terminologies }\end{array}$} & OTC & Know & 10 & 8 & 8 & 6.7 & 23 & 17.3 & 41 & 11.1 \\
\hline & POM & Know & 1 & 0.6 & 14 & 11.7 & 7 & 5.3 & 22 & 5.9 \\
\hline & t.i.d & Know & 73 & 62.4 & 98 & 81.7 & 74 & 55.6 & 245 & 66 \\
\hline & b.i.d & Know & 70 & 60 & 94 & 78.3 & 75 & 56.4 & 239 & 64.4 \\
\hline & q.i.d & Know & 48 & 35.2 & 36 & 30 & 30 & 22.6 & 106 & 28.6 \\
\hline & h.s & Know & 33 & 27.2 & 1 & 0.8 & 12 & 9 & 46 & 12.4 \\
\hline & q.d & Know & 10 & 8.8 & 9 & 7.5 & 25 & 18.8 & 44 & 11.9 \\
\hline & Sos & Know & 47 & 40 & 55 & 45.8 & 51 & 38.3 & 153 & 41.2 \\
\hline & p.r.n & Know & 6 & 5.6 & 1 & 0.8 & 9 & 6.8 & 16 & 4.3 \\
\hline \multirow{12}{*}{$\begin{array}{l}\text { Knowledge about } \\
\text { status of drugs }\end{array}$} & Panadol & Know & 103 & 85.6 & 78 & 65 & 97 & 72.9 & 278 & 74.9 \\
\hline & Brufen & Know & 102 & 84 & 70 & 58.3 & 93 & 69.1 & 265 & 71.4 \\
\hline & Dulcolax & Know & 85 & 69.4 & 48 & 40 & 70 & 52.6 & 203 & 54.7 \\
\hline & Surbex T & Know & 83 & 68.8 & 48 & 40 & 67 & 50.4 & 198 & 53.4 \\
\hline & Klaricid & Know & 85 & 72 & 86 & 71.7 & 67 & 50.4 & 238 & 64.2 \\
\hline & Lexotanil & Know & 111 & 92.8 & 88 & 73.3 & 91 & 68.4 & 290 & 78.2 \\
\hline & Deltacortil & Know & 104 & 87.2 & 89 & 74.2 & 79 & 59.4 & 272 & 73.3 \\
\hline & Septran & Know & 44 & 37.6 & 58 & 48.3 & 31 & 23.3 & 133 & 35.8 \\
\hline & Fansidar & Know & 72 & 60.8 & 76 & 63.3 & 58 & 43.6 & 206 & 55.5 \\
\hline & Augmentin & Know & 64 & 54.6 & 72 & 60 & 48 & 36.1 & 184 & 49.6 \\
\hline & Flagyl & Know & 32 & 25.6 & 35 & 29.4 & 17 & 12.8 & 84 & 22.6 \\
\hline & Lomotil & Know & 45 & 38.4 & 35 & 29.2 & 55 & 41.4 & 135 & 36.4 \\
\hline
\end{tabular}

into the reasons of prevailing practices. Seventy two percent of dispensers claimed to have some knowledge of regulations while $17.3 \%$ (64) claimed that they are not practised. Twenty seven percent of dispensers were of the view that regulations for pharmacies are harsh while $46 \%$ (171) believed that they are acceptable. The sale of prescription only medicines without prescription was considered as a problem by $80 \%$ (297) of the dispensers.

Over $90 \%$ (354) of dispensers thought that selling medicine is a good job and $73.6 \%$ (273) would also recommend this to their families while $80 \%$ (302) were satisfied with their current job as dispensers. Being an honourable and respectable job $53.6 \%$ (199) with ample profits $26.4 \%$ (98) and an opportunity to be updated with current knowledge $9.1 \%$ (25) were the reasons for joining this profession. Dispensers were of the view that they are capable of meeting the demands of the profession fully $73.6 \%$ (273), to some extent $21.8 \%$ (81) while $4.6 \%$ (17) believed that they are not meeting the demands at all. Some of the problems faced by the dispensers in the profession were patient demand of medicines without prescription $11.4 \%$ (42), return of expired drugs to the pharmaceutical companies $11.4 \%$ (42), time consuming profession due to long working hours $10 \%(37)$, regulation $7.9 \%(29)$, and availability of many brands in the market $7.6 \%(28)$, less profit margin $4.7 \%$ (25), drug supply issues $3.8 \%$ (14) and illegible prescriptions $1.6 \%$ (6).

Over $90 \%$ (339) of dispensers believed that dispensing in their pharmacy was appropriate. The reasons claimed were no complaints from patients $12.1 \%$ (44), ample experience $7.1 \%$ (26), following regulations $26.6 \%$ (97), having compounding services $0.5 \%$ (1), carrying out patient counseling $11.5 \%$ (42), selling full range of medicines in good locality $5.8 \%$ (17) and presence of qualified person $3 \%$ (10). But still over $80 \%$ (241) of dispensers felt that they are far behind when compared to international standards of dispensing practices. The dispensers notify that they can contribute to the profession through following regulations $25.3 \%$ (94), by promoting generics $3.8 \%$ (14), by lowering the prices $4 \%(15)$, improving drug availability $1.6 \%(6)$, by tackling with unethical marketing $5.7 \%(21)$ and this could be achieved by improving the regulators attitude $4.3 \%$ (16). Ninety percent dispensers identified the need for training with $85 \%$ (313) with the consent of attending if opportunity provided.

The median obtained for the knowledge of dispensers working at community pharmacies in the three cities was 33 (31-37) which when compared with reference scale (22-44) showed inadequate knowledge. While the median obtained in individual cities was 32 (29-35) in Islamabad, 34 (32-36) in Peshawar and 35 (31-38) in Lahore. The knowledge of dispensers working in community pharmacies in Islamabad was comparatively better than in Peshawar and Lahore.

Kruskal-Wallis test was used to compare the knowledge of dispensers having different levels of education, working experience in three different cities regarding storage temperature, prescription terminologies and status of medicines. A significant difference $(p \leq 0.05)$ in the knowledge of dispensers working at community pharmacies in the three cities was observed. Knowledge of dispensers working at community pharmacies in Islamabad was comparatively better than dispensers working in Peshawar and Lahore (Table 3). 


\begin{tabular}{|c|c|c|c|c|c|c|c|c|c|}
\hline \multirow{2}{*}{ Indicator } & \multirow{2}{*}{ Description } & \multicolumn{2}{|c|}{ Islamabad } & \multicolumn{2}{|c|}{ Peshawar } & \multicolumn{2}{|c|}{ Lahore } & \multicolumn{2}{|c|}{ Composite } \\
\hline & & $F$ & $\%$ & $\mathrm{~F}$ & $\%$ & $\mathrm{~F}$ & $\%$ & $F$ & $\%$ \\
\hline \multirow{9}{*}{$\begin{array}{l}\text { Source of information } \\
\text { regarding medicines }\end{array}$} & Books & 118 & 100 & 53 & 44.2 & 67 & 50.4 & 238 & 64.2 \\
\hline & Internet & 3 & 2.3 & 0 & 0 & 3 & 2.3 & 6 & 1.6 \\
\hline & $\begin{array}{l}\text { Medical } \\
\text { representative }\end{array}$ & 38 & 32 & 41 & 34.2 & 41 & 30.8 & 120 & 32.3 \\
\hline & $\begin{array}{ll}\text { Drug } & \text { company } \\
\text { literature } & \\
\end{array}$ & 47 & 40 & 30 & 25 & 43 & 32.3 & 120 & 32.3 \\
\hline & Distributors & 16 & 14.4 & 3 & 2.5 & 8 & 6 & 27 & 7.3 \\
\hline & Senior staff & 31 & 26.4 & 45 & 37.5 & 30 & 22.6 & 106 & 28.6 \\
\hline & $\begin{array}{l}\text { Neighbouring } \\
\text { chemist }\end{array}$ & 16 & 12.8 & 23 & 19.2 & 9 & 6.8 & 48 & 12.9 \\
\hline & $\begin{array}{l}\text { Product information } \\
\text { inserts }\end{array}$ & 47 & 39.3 & 17 & 14.2 & 17 & 12.8 & 81 & 21.8 \\
\hline & Others & 3 & 4 & 25 & 20.8 & 13 & 9.8 & 41 & 11.11 \\
\hline \multirow{5}{*}{$\begin{array}{l}\text { Frequency of information } \\
\text { regarding medicines used }\end{array}$} & Daily & 33 & 27.2 & 23 & 19.2 & 19 & 14.3 & 75 & 20.2 \\
\hline & Twice a week & 5 & 4.8 & 5 & 4.2 & 9 & 6.8 & 19 & 5.1 \\
\hline & Once a week & 17 & 13.6 & 6 & 5 & 10 & 7.5 & 33 & 8.9 \\
\hline & Monthly & 11 & 9.6 & 12 & 10 & 16 & 12 & 39 & 10.5 \\
\hline & Others & 52 & 44.8 & 74 & 61.7 & 79 & 59.4 & 205 & 55.3 \\
\hline \multirow{5}{*}{$\begin{array}{l}\text { Kind of information } \\
\text { consulted from medicines } \\
\text { information sources }\end{array}$} & Alternatives & 53 & 44.8 & 38 & 31.7 & 32 & 24.1 & 123 & 33.2 \\
\hline & Dosing regimen & 15 & 12.8 & 24 & 20 & 17 & 12.8 & 56 & 15.1 \\
\hline & Prices & 9 & 8 & 26 & 21.7 & 9 & 6.8 & 44 & 11.9 \\
\hline & Uses & 35 & 30.4 & 23 & 19.2 & 27 & 20.3 & 85 & 22.9 \\
\hline & Others & 33 & 26.4 & 45 & 37.5 & 36 & 27.1 & 114 & 30.7 \\
\hline
\end{tabular}

\begin{tabular}{|l|c|c|c|c|}
\hline \multicolumn{6}{|c|}{ Table 3. Comparison of knowledge of dispensers working at community pharmacies in the three cities } \\
\hline Indicator & $\begin{array}{c}\text { Knowledge about } \\
\text { storage temperature }\end{array}$ & $\begin{array}{c}\text { Knowledge about prescription } \\
\text { terminologies }\end{array}$ & $\begin{array}{c}\text { Knowledge about status } \\
\text { of medicines }\end{array}$ & Composite \\
\hline $\mathrm{N}$ & $\begin{array}{l}\text { Islamabad }=118 \\
\text { Peshawar }=120 \\
\text { Lahore }=133\end{array}$ & $\begin{array}{l}\text { Islamabad }=118 \\
\text { Peshawar }=120 \\
\text { Lahore }=133\end{array}$ & $\begin{array}{l}\text { slamabad }=118 \\
\text { Peshawar }=120 \\
\text { Lahore }=133\end{array}$ & $\begin{array}{l}\text { Islamabad }=118 \\
\text { Peshawar }=120 \\
\text { Lahore }=133\end{array}$ \\
\hline $\mathrm{H}$ & 83.387 & 2.949 & 24.206 & 32.218 \\
\hline $\mathrm{P}$ value & 0.000 & 0.225 & 0.000 & 0.000 \\
\hline Kruskal Wallis Test at $\mathrm{p}=0.05 \quad$ Significant at $(p<0.05)$ & \multicolumn{3}{c|}{} \\
\hline
\end{tabular}

A significant difference $(p \leq 0.05)$ in the knowledge of dispensers working at community pharmacies with different experience and levels of education was observed. The dispensers in Lahore having experience less than one year had relatively better knowledge. While pharmacists were having comparatively better knowledge regarding storage temperature, prescription terminologies and status of medicines as compared to pharmacy assistants, diploma holders and salesperson (Table 4).

Mann Whitney and kruskal-wallis tests $(p \leq 0.05)$ were used to compare impact of training, status in pharmacy and rural/urban setting on the knowledge of dispensers working at community pharmacies in the three cities. No significant difference was observed among the knowledge of dispensers working at community pharmacies with different status (license, owner, spouse and employee), rural/urban setting and training in the three cities.

\section{DISCUSSION}

The overall qualification, knowledge and training of dispensers working at community pharmacies in Pakistan is inadequate. Pharmacies are largely operated by non qualified and untrained dispensers. The results of the study highlight that most of the dispensers working at community pharmacies are not qualified but have ample years of experience.
Nevertheless this experience of dispensers does not reflect in their better knowledge. Low knowledge of dispensers and absence of qualified person has also been reported by several studies from developing countries. ${ }^{6-8,15,16}$ All of the dispensers working at community pharmacies were males this can be linked to cultural and social barriers in Pakistan where females are not encouraged to work in premises where they have to interact directly with the males, same is the cases with the community pharmacies. However, this might not be similar in other courtiers where majority of females are also engaged at community pharmacies. ${ }^{24,25}$ The presence of legally qualified persons is negligible at the pharmacies and in most of the cases owners are substituting the qualified person. Similar findings have been reported from India where on record every community pharmacy has a qualified person but in reality few are present; day to day dispensing is carried out by the owners of the pharmacies, spouse or employees. ${ }^{15}$

The dispensers having experience of less than one year were having better knowledge in Lahore city. This might be linked to more number of pharmacist and fresh graduates with updated knowledge working at community pharmacies in Lahore and also reflects on the changes occurring in the pharmacy curriculum which places increased emphasis on practice related subjects. Similar results were reported in another study from 


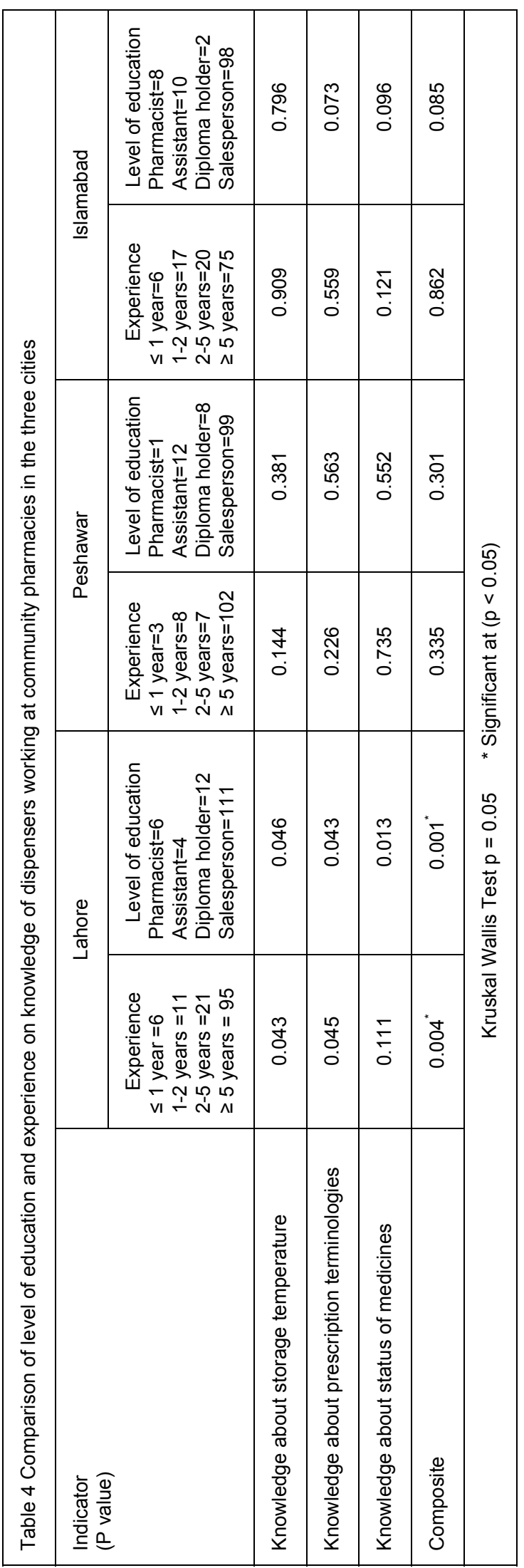

Republic of Moldova where younger pharmacists appear to identify more with current trends in the practice of pharmacy such as professional activities related to the delivery of pharmaceutical care. ${ }^{24}$ These findings also support the concept that as the knowledge base of graduates changes and they move into practice, they will influence practice change, to reflect the new knowledge base. On the other hand, study from Kenya reported that although the dispensers had ample experience of working at pharmacies but their knowledge and patient management was poor in case of sexually transmitted infections. ${ }^{16}$

A large number of dispensers working at community pharmacies in Pakistan lack training and formal education as per their job requirement. Study from Cambodia reported that almost fifty percent of drug sellers had only high school education and in majority of the cases dispensers had no formal training ${ }^{17}$, similar fact has also been reported by a study in Karachi, Pakistan. ${ }^{7}$

The study highlighted deficiencies in basic knowledge of dispensers regarding prescription terminologies, similar findings were reported from a study conducted in Karachi, Pakistan. ${ }^{7}$ This fragmentary knowledge in terms affects the quality of communication with the patient. To ensure the integrity of pharmaceutical products it is important to store them appropriately. It was alarming to note that half of the dispensers interviewed were ignorant of the room temperature for storage of medicines and about two third of dispensers did not know about storage temperature for vaccines, fridge temperature and medicines to be kept in fridge. Similar facts have been reported by a study conducted in Rawalpindi, Pakistan. ${ }^{8}$

The community pharmacies are obliged to stay updated and comply with regulations. The ability of staff to deal with medicines requests at community pharmacies is very important. It has been a common observation that community pharmacies in low income countries usually dispense prescription only medicines on customers demand without having any concern. ${ }^{22}$ Similar findings were reported in a study from Ghana which revealed that drug retailers had little or no training in pharmacy, sale of prescription only medicines according to popular demand and provision of misinformation regarding use of medicines was a common practice. ${ }^{26}$ Although results of the present study showed that mmajority of dispensers working at community pharmacies claimed that selling POM medicines without prescription is a problem but on the other hand most of them were unaware regarding status of various prescription only medicines such as Augmentin $\circledast$ (Coamixiclave), Septran ${ }^{\circledR}$ (Sulfamethoxazole) and Flagyl® (Mentronidazole)were considering them as over the counter drugs and were involved in their sale without any prescription. Another study from Rawalpindi, Pakistan also highlighted similar practice of selling POM medicines without prescription by high percentage of community pharmacies. ${ }^{8}$ This practice can be linked to inadequate knowledge, qualification and training of dispensers. $^{7}$

With this poor state of knowledge majority of dispensers working at community pharmacies believed that they are capable of meeting the demands of their profession. It was interesting to observe that dispensers believed that by having no 
complaints, ample experience, following regulations and keeping full range of medicines they are fulfilling the demand of the profession. This highlights confusion and lack of awareness regarding professional responsibilities among dispensers. The present study highlighted that only few dispensers received any formal training in the past years but this training could not translate into their better knowledge. This raises questions on the quality of training received by dispensers in the country. Although studies have highlighted on improvements in knowledge of dispensers with training. ${ }^{18,19}$ Majority of them expressed willingness to learn and participate if any opportunity of training is provided. Similar willingness of dispensers to participate in training was reported from India. ${ }^{17}$

Even though dispensers don't possess proper tools to function, in terms of qualification and knowledge but still they are satisfied with their job and would also recommend this to others as they feel it as a profitable white collar business with least demand from regulators and society. This fact can be linked with lack of an accountable regulatory framework, proper implementation of health policies and political instability in the country. ${ }^{27}$ The low priority given to the health sector, lack of human resources, and lack of interest by the government has resulted in a persistent contrast between reasonable economic growth and government expenditure on health. ${ }^{28}$ Legal reform is required to achieve the health objectives in order to contribute towards accomplishment of the global Millennium Development Goals (MDG) and acceptance of the pharmacy profession as an integral part of a wellstructured health care system.

\section{CONCLUSIONS}

The importance of qualification, experience, training and knowledge of dispensers working at community pharmacies is not much emphasized in the country. Knowledge of dispensers working at community pharmacies is an important determinant of pharmacy practice. Experience alone cannot serve the purpose. Lack of proper qualification, training and adequate knowledge of dispensers are currently the main hurdles in achieving effective health of general public attending community pharmacies in Pakistan. Improving the knowledge of dispensers might be a slow process but can be achieved by the active involvement of different program stake holders and changes in national policies.

\section{CONFLICT OF INTEREST}

The authors declare that there is no conflict of interest. The study was partially funded by Research \& Development program of Ministry of Health, Government of Pakistan.

\section{References}

1. Azhar S, Hassali MA, Ibrahim MI, Ahmad M, Masood I, Shafie AA.The role of pharmacists in developing countries: the current scenario in Pakistan. Hum Resour Health.2009:7:54.

2. Kafle KK, Gartoulla RP, Pradhan YM, Shrestha AD, Karkee SB, Quick JD. Drug retailer training: Experiences from Nepal. Soc Sci Med. 1992;35(8):1015-1025.

3. Chuc NTK, Tomson G. "Doi moi" and private pharmacies: a case study on dispensing and financial issues in Hanoi, Vietnam. Eur J Clin Pharmacol. 1999;55(4):325-332.

4. Syhakhang L, Lundborg CS, Lindgren B, Tomson G. The quality of drugs in private pharmacies in Lao PDR: a repeat study in 1997 and 1999. Pharm World Sci. 2004;26(6):333-338.

5. Stenson B, Syhakhang L, Eriksson B, Tomson G. Real world pharmacy: assessing the quality of private pharmacy practice in the Lao People's Democratic Republic. Soc Sci Med. 2001;52:(3):393-404.

6. Mac TL, Le VT, Vu AN, Preux PM, Ratsimbazafy V. AEDs availability and professional practices in delivery outlets in a city center in southern Vietnam. Epilepsia. 2006;47(2):330-334.

7. Rabbani F, Cheema FH, Talati N, Siddiqui S, Syed S, Bashir S, Zuberi LZ, Shamim A, Mumtaz Q. Behind the counter:pharmacies and dispensing patterns of pharmacy attendants in Karachi. J Pak Med Assoc. 2001;51(4):149-153.

8. Butt ZA, Gilani AH, Nanan D, Sheikh AL, White AF. Quality of pharmacies in Pakistan: a cross-sectional survey. Int J Qual Health Care. 2005;17(4):307-313.

9. Chalker J, Chuc NT, Falkenberg T. Private pharmacies in Hanoi, Vietnam: a randomized trial of a 2-year multicomponent intervention on knowledge and stated practice regarding ARI, STD and antibiotic/steroid requests. Trop Med Int Health. 2002;7(9):803-810

10. Qidwai W, Krishanani MK, Hashmi S, Afridi M, Ali RA. Private Drug Sellers Education in Improving Prescribing Practices. J Coll Physicians Surg Pak. 2006;16(12):743-746.

11. Rajakaruna RS, Weerasinghe $M$, Alifrangis $M$, Amerasinghe $\mathrm{PH}$, Konradsen $\mathrm{F}$. The role of private drug vendors as malaria treatment providers in selected malaria endemic areas of Sri Lanka. J Vector Borne Dis. 2006;43(2):58-65.

12. Das BP, Deo SK, Jha N, Rauniar GP, Naga Rani MA. Knowledge, attitudes and practices (KAP) regarding the management of diarrhea by pharmacists and licensed drug sellers in eastern Nepal. Southeast Asian J Trop Med Public Health. 2005;36(6):1562-1567.

13. Hetzel MW, Dillip A, Lengeler C, Obrist B, Msechu JJ, Makemba AM, Mshana C, Schulze A, Mshinda H. Malaria treatment in the retail sector: knowledge and practices of drug sellers in rural Tanzania.BMC Public Health. 2008;8:157.

14. Syhakhang L, Freudenthal S, Tomson G, Wahlström R. Knowledge and perceptions of drug quality among drug sellers and consumers in Lao PDR. Health Policy Plan. 2004;19(6):391-401.

15. Oun S, Edward-Raj A, Ojuola O, Bowman G, Long WM. Assessing the quality of health services provided by informal drug sellers in rural Cambodia. American Public Health Association 133rd Annual Meeting \& Exposition. Philadelphia, 10-14 Dec 2005. 
16. Wolffers I.. Drug information and sale practices in some pharmacies of Colombo, Sri Lanka. Soc Sci Med. 1987;25(3):319-321.

17. Poudel A, Khanal S, Alam K, Palaian S. Perception of Nepalese community pharmacists towards patient counseling and continuing pharmacy education program: A multicentric study. J Clin Diag Res. 2009;(3):1408-1413

18. Kamat VR, Nichter M. Pharmacies, self-medication and pharmaceutical marketing in Bombay, India. Soc Sci Med. 1998;47:779-794.

19. Kwena Z, Sharma A, Wamae N, Muga C, Bukusi E. Provider characteristics among staff providing care to sexually transmitted infection self-medicating patients in retail pharmacies in Kibera slum, Nairobi, Kenya. Sex Transm Dis. 2008;35(5):480-483.

20. Rovers JP, Currie JD, Hagel HP, McDonough RP, Sobotka JL: A practical guide to pharmaceutical care Washington, DC: American Pharmaceutical Association; 2003.

21. Abdul RBK, Fahmy SA, Abu-Gharbieh EF, Ali HS. Professional practices and perception towards rational use of medicines according to WHO methodology in United Arab Emirates. Pharmacy Practice (Internet).2010;8(1):70-76.

22. Larsson M, Tomson G, Binh NT, Chuc NTK, Falkenberg T. Private pharmacy staff in Hanoi dispensing steroids -theory and practice. Pharmacy Practice (Internet). 2006; 4(2):60-67.

23. Israel GD. 1992. Determining Sample Size. Program Evaluation and Organizational Development, IFAS, University of Florida. PEOD-6. November.

24. Cordina M, Safta V, Ciobanu A, Sautenkova N. An assessment of community pharmacists attitudes towards professional practice in the Republic of Moldova. Pharmacy Practice (Internet). 2008;6(1):1-8.

25. Hale ZT, Ahmet A, Sule O, Sanda C, Sena FS, Meral KU. The pharmacy practice of community pharmacists in Turkey. Marmara Pharmaceutical J. 2010;14:53-60.

26. Wolf-Gould CS, Taylor N, Horwitz SM, Barry M. Misinformation about medications in rural Ghana. Soc Sci Med. 1991;33(1):83-89.

27. Khan MM, Van den Heuvel W. The impact of political context upon the health policy process in Pakistan. Public Health. 2007;121(4):278-286.

28. Government of Pakistan, Finance Division, Wing EA: Economic survey of Pakistan, 2005-2006. Islamabad. 2006. 